\title{
Product Cost Management via the Kaizen Costing System: Perception of Accountants
}

\author{
Pius Vincent Chukwubuikem Okoye ${ }^{1}$, Francis Chinedu Egbunike ${ }^{1} \&$ Olamide Mofolusho Meduoye ${ }^{2}$ \\ ${ }^{1}$ Department of Accountancy, Nnamdi Azikiwe University, Awka, Nigeria \\ ${ }^{2}$ First Bank of Nigeria (FBN) Ltd., Nigeria \\ Correspondence: Egbunike Francis Chinedu, Department of Accountancy, Nnamdi Azikiwe University, P.M.B. \\ 5025, Awka, Anambra State, Nigeria. Tel: 234-813-285-0409. E-mail: chineduegbunike@rocketmail.com
}

\author{
Received: May 27, $2013 \quad$ Accepted: August 5, $2013 \quad$ Online Published: November 18, 2013 \\ doi:10.5539/jms.v3n4p114 URL: http://dx.doi.org/10.5539/jms.v3n4p114
}

\begin{abstract}
Managing cost of production is at the heart of survival of present day corporations, as increased competition, uncertainty and risk present in the operating environment pose challenges for $21^{\text {st }}$ century managers. This empirical paper examines product cost management strategies by adopting and implementing the Kaizen Costing System. The sample size of the study was 60 respondents comprising accountants distributed across product and service sector organisations in Anambra State, south-eastern Nigeria. Three hypotheseswere formulated and tested in the study. In addition to descriptive statistics, Mann-Whitney U, Kolmogorov-Smirnoff and Multivariate Analysis of Variance (MANOVA) were used in analyzing the primary data. The results ofthe data analysis showed that implementing a Kaizen Costing System would provide managers with strategies for reducing material procurement and usage costs, and also reduce labour utilization cost. Respondents also perceived a link between cost reduction strategies at the minimal batch production phase and the maximum batch production phase. Based on this, the study recommends that Nigerian manufacturing firms should adoptand implementthe Kaizen Costing System, this should however not be done in isolation as such a system would require corporate strategy overhaul and alignment, a kaizen culture was suggested as counterpart in the system implementation for incorporation at the strategic level.
\end{abstract}

Keywords: Kaizen Costing System (KCS), product cost management

\section{Introduction}

The financial system of various economies has witnessed a down-turn, in the aftermath of the global financial crisis of 2008 and beyond (Osisioma, 2010). Most economies are still battling with adjustment programs meant to combat the impact of the crisis. Corporations in these economies are not left out, as access to finance constantly declines primarily due to volatility of the capital market; corporations are forced to down scale the size of their operating activities. Osisioma (2010) observed that manufacturing firms, particularly automobile industries witnessed a drop in sales level, an accumulation of unsold stocks, and a declining demand level leading to a fall in profit level. Thus, managing cost of production is therefore the focal point of any manager, as increased competition in the modern business environment among companies; coupled with a turbulent market system, allowing for free entry and exit of market participants, the choice of a product by a consumer is highly dependent on the consumers perceived value of the product and the availability of substitutes. Thus, with the growing presence of 'vocal customers' (Sani \& Allahverdizadeh, 2012), demanding high quality products at lower prices (Jayeola, Sokefun, \& Oginni, 2012) companies are necessitated to upgrade or modify their processes 'constantly' in order to lower cost of products or services they trade (Budugan \& Georgescu, 2009) in order to, stay ahead of competition and meet the growing customer demands (Sani \& Allahverdizadeh, 2012). This can only be achieved through process redesign measures aimed at cost reduction (Sani \& Allahverdizadeh, 2012) with a resulting effect on the market price of the product.

Mishra and Gupta (2010) observed that the change factor rendering uniqueness and competitiveness to any company is the quality of its final product and/or service rendered to customers. Managers are therefore faced with a dual objective: achieving improvements in product or service quality and simultaneously managing production cost. Thus, managing cost of production is at the centre of survival for modern corporations (Jayeola, Sokefun, \& Oginni, 2012), given the advances of the $21^{\text {st }}$ century causing dramatic changes in the production 
process; the 'survival triplet' for modern day corporations is on how 'to manage product/service cost, quality and performance' (Innes \& Mitchell, 1991, cited in Jayeola, Sokefun, \& Oginni, 2012). Thus, a market driven change is fundamental which should be implemented through small gradual processes targeted at areas which impact on 'profitability, competitiveness and growth' (Mishra \& Gupta, 2010).

To calculate and manage product costs, a critical understanding of the tasks or activities that generate such costs is needed by managers (Budugan \& Georgescu, 2009). A cost system for understanding the impact of these value-added tasks or activities is therefore necessary, as most cost management systems ignore the effect of non-quantifiable attributes, such as: quality, throughput, flexibility, etc. in the manufacturing process and are in conflict with strategic management objectives (Berliner et al., 1988, cited in Modarress, Ansari, \& Lockwod, 2004). In this vein, the kaizen costing approach was developed and adopted initially by Japanese firms; the system is based on achieving small incremental adjustments in the product's manufacturing process, rather than the design process (target costing approach) so as to retain the product's functionality in line with customer requirements being a key to successful demand conditions. This is because managers utilize the approach to eliminate costs after achieving learning experiences and conducting value-analysis at each stage of the production process. The continuous cost reduction involves four dimensions which must be integrated in the management of an organization (Epuran, Băbăită, \& Grosu, 1999, cited in Budugan \& Georgescu, 2009):

- Taking into account the operating environment of the business, such as: markets and the activities of competitors;

- Integrating the skills of the various functions of the enterprise;

- Viewing product decisions from a futuristic perspective i.e. effect of current decisions on future outcomes; and,

- Creating a more stringent connection between budgeting and the control of the current activity.

Thus, the entire process is holistic in nature comprising the activities of all departments in the organization, which can be achieved through effective communication procedures and the institutionalization of a Kaizen Culture at the corporate strategic level.

\subsection{Objectives of the Study}

The main objective of this study is to determine whether the implementation of a Kaizen Costing System (KCS) would provide managers with strategies for reducing costs associated with different stages of the Manufacturing Life Cycle. Three phases of the manufacturing life cycle were identified, thus: the introductory phase (prototype creation/development), minimal batch production phase (growth stage) and maximum batch production (maturity stage).

More specifically, this study shall address the following objectives:

1) To determine whether the implementation of a Kaizen Costing System would provide managers with cost reduction measures at the product's introductory phase.

2) To determine whether the implementation of a Kaizen Costing System would provide managers with cost reduction measures at the minimal batch production phase.

3) To determine whether the implementation of a Kaizen Costing System would provide managers with cost reduction measures at the maximum batch production phase.

\subsection{Research Questions}

1) To what extent would the implementation of a Kaizen Costing System provide managers with cost reduction measures at the product's introductory phase?

2) To what extent would the implementation of a Kaizen Costing System provide managers with cost reduction measures at the minimal batch production phase?

3) To what extent would the implementation of a Kaizen Costing System provide managers with cost reduction measures at the maximum batch production phase?

\subsection{Research Hypotheses}

$\mathrm{H}_{1}$ : The implementation of a Kaizen Costing System would not provide managers with cost reduction measures at the product's introductory stage.

$\mathrm{HO}_{2}$ : The implementation of a Kaizen Costing System would not provide managers with cost reduction measures at the minimal batch production phase. 
$\mathrm{HO}_{3}$ : The implementation of a Kaizen Costing System would not provide managers with cost reduction measures at the maximum batch production phase.

\section{Literature Review}

\subsection{Kaizen Costing System (KCS)}

Kaizen a term with Japanese origin (Sani \& Allahverdizadeh, 2012), was launched by Masaaki Imai (Rof, 2012), the concept is a coinage of two Japanese words: KAI (Change) and ZEN (for better) (Rof, 2012). Thereafter, Yashuhiro Monden from Japan developed Kaizen Costing as the costing counterpart to the Kaizen approach (Industrial and Financial Systems, 2001). This concept refers to the process of 'continuous improvement' (Rof, 2012; Sani \& Allahverdizadeh, 2012).The principle behind Kaizen Costing application is on achieving small, gradual but continuous improvements in the productionprocess at minimal cost (Rof, 2012). Ellram (2000, cited in Modarress, Ansari, \& Lockwod, 2004) observed that Kaizen Costing ensures that products meets or exceeds customer demands for 'quality, functionality, and prices' in order to sustain the product's competitiveness. This according to Rof (2012) can be achieved through a sequential elimination of all the processes that would increase the product's cost of production without a corresponding increase in value. Rof (2012) identified the following characteristics as ensuring the successfulness of the Kaizen Costing approach:

- It lays no emphasis on the present existing situation, by disregarding all ideas implemented in the production process;

- The system does not strive for perfection, rather seeking gradual improvementsinthe existing situation, at an acceptable cost;

- It allows managers to exercise discretion in the application of their knowledge and personal skills;

- It encourages collective decision - making, i.e. the ideas of many are better than that of one single person;

- There are no limits to the level of improvements that can be implemented.

According to Budugan and Georgescu (2009) Kaizen Costing involves the planning team, after establishing and implementing the product and process design, to focus on the operational character of the process and on its development in the most efficient manner.

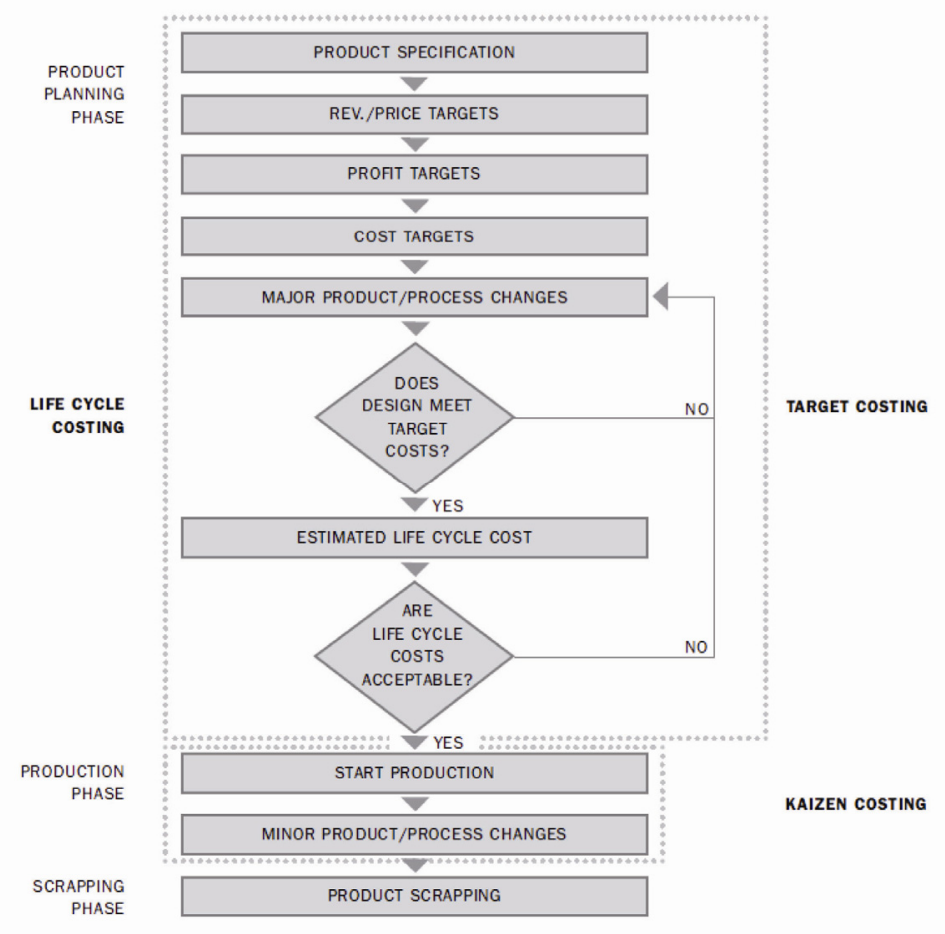

Figure 1. Kaizen costing implementation stages

Source: Industrial and Financial Systems (2001). 
Target Costing and Kaizen Costing methods are similar costing techniques which follow a target, but the following differences can be still be noted among the two (Rof, 2012):

1) Focus: In Target Costing customers' product requirements are the focal point, whereas in Kaizen Costing the profitability of the objectives set by the managers;

2) Application: Target Costing is applied by the product design team before the product is manufactured, whereas the Kaizen Costing is applied during the manufacturing process of the product.

The basic principle guiding the implementation of a Kaizen Costing System is on achieving overall cost reductions during the product's manufacturing process, through the integrated effort of all departments and persons directly involved in the production process. When compared with standard costing, the Kaizen cost analysis 'examines the difference between the target Kaizen costs and the actual cost reduction achieved' (Malaysian Export Academy, 2012). The basic idea in doing this is to achieve 'incremental cost reductions on a continual basis in a product's life cycle' (Malaysian Export Academy, 2012).

The application of the Kaizen Costing (KC) method involves the improvement of the production process via (Budugan \& Georgescu, 2009):

$>$ Optimization of the launch system in fabrication;

$>$ Setting the machines;

$>$ Increase of the performances of the machines;

$>$ Staff formation and motivation; and,

$>$ Encouragement of the staff charged with the identification of the cost reduction possibilities.

In order to achieve the continuous cost reduction objectives, kaizen budgeting must target the entire organization, and this involves adequate management which must focus on the following aspects:

- Control of all the phases of the lifecycle of a product or service;

- Making sure, in a progressive manner, that the new products will be profitable throughout the entire duration of their life cycle (monitoring of the costs during this cycle by comparing the estimates and the obtained results, with reference to the selling price of the competition)

- Establishing all the elements of the supply chain, inclusive for the suppliers of parts and collaborators, the objective of the continuous search of opportunities for reducing costs.

- Mobilization and motivation of all the competencies within an organization via a transversal approach, thus favouring competitiveness.

In a study of Kaizen Costing practice among SMEs, Jayeola, Sokefun and Oginni (2012) using a sample of 269 respondents purposively drawn from SMEs in agro-allied (72); confectioneries (67); general trading (71) and transport (59); distributed across the three senatorial districts in Ogun state, Nigeria, empirically tested for relationship between cost components and profitability. The Chi-square value was given as $13.034(\mathrm{p}<0.05)$ showing that a relationship existed. The test of the relationship between kaizen cost management technique and survival of the SMEs gave a Chi-square value of $10.445(\mathrm{p}<0.05)$. The results of the Logistic Regression showed that only the fixed cost with Beta value of 2.309; was the most significant cost component that affected the average annual profit.

\section{Research Design and Methodology}

The research design utilized in this study is the descriptive survey method. The primary data was obtained from questions structured using the five point likert scale with the following options: Strongly agree (SA); Agree (A); Indifferent (ID); Disagree (D); Strongly disagree (SD) with associated weights of 5, 4, 3, 2 and 1 respectively. Respondents comprised 60 accountants, distributed across product and service organizations in Awka, Anambra state in south-eastern Nigeria. The following statistical methods were employed in the presentation and analysis of data: Frequency table, Kolmogorov-Smirnoff test and Multivariate Analysis of Variance (MANOVA). The results are presented below. 
Table 1. Sex of respondents

\begin{tabular}{llllll}
\hline & & Frequency & Percent & Valid Percent & Cumulative Percent \\
\hline Valid & Male & 44 & 73.3 & 73.3 & 73.3 \\
& Female & 16 & 26.7 & 26.7 & 100.0 \\
& Total & 60 & 100.0 & 100.0 & \\
\hline
\end{tabular}

Source: Field Survey (2013); SPSS ver. 17.0.

From the table above, Table 1, 44 representing 73.3 percent of the respondents are males while 16 representing 26.7 percent of respondents are females.

Table 2. Nature of industry

\begin{tabular}{llllll}
\hline & & Frequency & Percent & Valid Percent & Cumulative Percent \\
\hline Valid & Product & 30 & 50.0 & 50.0 & 50.0 \\
& Service & 30 & 50.0 & 50.0 & 100.0 \\
& Total & 60 & 100.0 & 100.0 & \\
\hline
\end{tabular}

Source: Field Survey (2013); SPSS ver. 17.0.

From the table above, Table 2, the respondents are uniformly distributed across the two sectors: 30 representing 50 percent are in product sector organizations and 30 representing 50 percent are in service sector organizations.

Table 3. Highest level of educational qualification

\begin{tabular}{llllll}
\hline & & Frequency & Percent & Valid Percent & Cumulative Percent \\
\hline Valid & BSc/HND & 39 & 65.0 & 65.0 & 65.0 \\
& MSc/MBA & 15 & 25.0 & 25.0 & 90.0 \\
& PHD & 6 & 10.0 & 10.0 & 100.0 \\
& Total & 60 & 100.0 & 100.0 & \\
\hline
\end{tabular}

Source: Field Survey (2013); SPSS ver. 17.0.

From the table above, Table 3, 39 representing 65 percent of the respondents are BSc/HND holders; 15 representing 25 percent of respondents are MSc/MBA holders, while only 6 representing 10 percent of respondents have PHD qualifications.

Table 4. Length of service in the organization

\begin{tabular}{llllll}
\hline & Frequency & Percent & Valid Percent & Cumulative Percent \\
\hline Valid & 1-10 years & 40 & 66.7 & 66.7 & 66.7 \\
& $11-20$ years & 20 & 33.3 & 33.3 & 100.0 \\
& Total & 60 & 100.0 & 100.0 & \\
\hline
\end{tabular}

Source: Field Survey (2013); SPSS ver. 17.0.

From the table above, Table 4, 40 representing 66.7 percent of the respondents have worked for a period ranging from 1-10 years, while 20 representing 33.3 percent of respondents have worked for a period ranging from 11-20 years. 


\section{Analysis and Presentation of Date}

\section{Consider Analysis Result for H1}

$\mathrm{HO}_{1}$ : The implementation of a Kaizen Costing System would not provide managers with cost reduction measures at the product's introductory stage.

Table 5. Between-subjects factors (hypothesis one)

\begin{tabular}{llll}
\hline \multirow{2}{*}{ Sex } & & Value Label & $\mathrm{N}$ \\
& 1.00 & Male & 44 \\
Nature of Industry & 2.00 & Female & 16 \\
& 1.00 & Product & 30 \\
Highest Level of Educational Qualification & 1.00 & BSc/HND & 30 \\
& 2.00 & MSc/MBA & 15 \\
& 3.00 & PHD & 6 \\
Length of service in the organisation & 1.00 & $1-10$ years & 40 \\
& 2.00 & $11-20$ years & 20 \\
\hline
\end{tabular}

Source: SPSS ver. 17.0 .

Table 6. Multivariate tests for hypothesis one

\begin{tabular}{llllllll}
\hline Effect & & Value & F & Hypothesis df & Error df & Sig. \\
\hline Intercept & Pillai's Trace & .982 & $653.576^{\mathrm{a}}$ & 4.000 & 47.000 & .000 \\
& Wilks' Lambda & .018 & $653.576^{\mathrm{a}}$ & 4.000 & 47.000 & .000 & \\
& Hotelling's Trace & 55.624 & $653.576^{\mathrm{a}}$ & 4.000 & 47.000 & .000 & .000 \\
\hline
\end{tabular}

Source: SPSS ver. 17.0.

\section{Consider Analysis Result for $\mathbf{H 2}$}

$\mathrm{HO}_{2}$ : The implementation of a Kaizen Costing System would not provide managers with cost reduction measures at the minimal batch production phase.

Table 7. Between-subjects factors (hypothesis two)

\begin{tabular}{llll}
\hline & & Value Label & $\mathrm{N}$ \\
\hline Sex & 1.00 & Male & 44 \\
\multirow{2}{*}{ Nature of Industry } & 2.00 & Female & 16 \\
& 1.00 & Product & 30 \\
Highest Level of Educational Qualification & 2.00 & Service & 30 \\
& 1.00 & BSc/HND & 39 \\
Length of service in the organisation & 2.00 & MSc/MBA & 15 \\
& 3.00 & PHD & 6 \\
\hline
\end{tabular}

Source: SPSS ver. 17.0. 
Table 8. Multivariate tests for hypothesis two

\begin{tabular}{lllllll}
\hline Effect & & Value & F & Hypothesis df & Error df & Sig. \\
\hline Intercept & Pillai's Trace & .956 & $349.344^{\mathrm{a}}$ & 3.000 & 48.000 & .000 \\
& Wilks' Lambda & .044 & $349.344^{\mathrm{a}}$ & 3.000 & 48.000 & .000 \\
& Hotelling's Trace & 21.834 & $349.344^{\mathrm{a}}$ & 3.000 & 48.000 & .000 \\
& Roy's Largest Root & 21.834 & $349.344^{\mathrm{a}}$ & 3.000 & 48.000 & .000 \\
\hline
\end{tabular}

Source: SPSS ver. 17.0

\section{Consider Analysis Result for $\mathrm{H3}$}

$\mathrm{H}_{3}$ : The implementation of a Kaizen Costing System would not provide managers with cost reduction measures at the maximum batch production phase.

Table 9. Ranks

\begin{tabular}{lllll}
\hline & $\begin{array}{l}\text { Nature of } \\
\text { Industry }\end{array}$ & $\mathrm{N}$ & Mean Rank & Sum of Ranks \\
\hline $\begin{array}{l}\text { Implementation of the Kaizen Costing System } \\
\text { at the maximum batch production phase would }\end{array}$ & Product & 30 & 26.60 & 798.00 \\
$\begin{array}{l}\text { ensure that unit costs from batch production } \\
\text { process are reduced }\end{array}$ & Total & 60 & 34.40 & 1032.00 \\
\hline
\end{tabular}

Table 10. Mann-Whitney \& Wilcoxon test result $\mathrm{t}^{\mathrm{a}}$

\begin{tabular}{ll}
\hline & $\begin{array}{l}\text { Implementation of the Kaizen Costing System at the maximum batch } \\
\text { production phase would ensure that unit costs from batch production } \\
\text { process are reduced }\end{array}$ \\
\hline Mann-Whitney U & 333.000 \\
Wilcoxon W & 798.000 \\
Z & -2.280 \\
Asymp. Sig. (2-tailed) & .023 \\
\hline
\end{tabular}

a. Grouping Variable: Nature of Industry.

Table 11. Kolmogorov-Smirnov test result $\mathrm{t}^{\mathrm{a}}$

\begin{tabular}{lll}
\hline & & $\begin{array}{l}\text { Implementation of the Kaizen Costing System at the } \\
\text { maximum batch production phase would ensure that } \\
\text { unit costs from batch production process are } \\
\text { reduced }\end{array}$ \\
\hline Most Extreme Differences & Absolute & .300 \\
Positive & .300 \\
Kolmogorov-Smirnov Z & Negative & -.100 \\
Asymp. Sig. (2-tailed) & 1.162 \\
\hline
\end{tabular}

a. Grouping Variable: Nature of Industry.

\section{Discussion of Findings}

The following findings emanated from the literature and empirical data analysis:

1) Respondents perceived that implementing a Kaizen Costing System would provide managers with techniques for reducing future material procurement costs (see question 2 with mean score of 4.55); they also 
agreed that implementing the KCS at the product's minimal batch production phase would provide management with strategies for reducing raw material consumption in the maximum batch production stage (see question 7 with mean score of 4.28).

2) Respondents also agreed that future labour acquisition costs can be targeted for reduction alternatives during process production (see question 3 with mean score of 4.33); while at the minimal batch production phase, implementing the KCS would provide management strategies for reducing labour utilization costs in the maximum batch production stage as a result of the learning curve effect (see question 8 with mean score of 3.5).

3) Respondents perceived that implementing an organizational based Kaizen culture would provide the production team with strategies for product improvement during design and manufacturing process (see question 5 with mean score of 4.00), by providing the production department with strategies for product development and enhancement as customer requirements are duly considered for improvements purpose (see question 9 with mean score of 4.03).

4) Implementing a Kaizen Culture would provide management with strategies to improve the future revenue profile of the organization as cost of production is constantly reduced (see question 10 with mean score of 4.38).

5) Respondents also agreed that implementing the Kaizen Costing System at the maximum batch production phase would ensure that unit costs from batch production process are reduced (see question 11 with mean score of 4.57); while also ensuring that profitability is high as products are adjusted periodically for changes in material and labour requirements (see question 12 with mean score of 4.32).

\section{Conclusion \& Recommendations}

The current speed of the globalization process facilitated by rapid advances in information technology (ICT) has posed a serious challenge for 21 st century corporations. Thus, corporate survival is a function of the extent to which organizations react positively to economic and corporate troughs (Ekwueme, Egbunike, \& Onyali, 2013). In this vein, Managing cost of production is at the focal point of present day management, as organizations compete in a highly turbulent environment managers are constantly seeking for cost reduction systems to implement.

1) Organizations are encouraged to adopt and implement the Kaizen Costing System to complement existing techniques in order to strengthen their cost reduction possibilities in present day markets. More especially the manufacturing sector as Nigeria advances to become one of the top 20 economies in its Vision 2020 agenda.

2) There is a need for organizations to adopt the Kaizen Costing System in addition with an atmosphere of corporate Kaizen Culture, so as to enable strategy alignment: Since a Kaizen System would entail synergy between the various departments of the organization. A Kaizen culture would ensure that activities of departments, especially the production department are complemented by activities of say the marketing department.

\section{References}

Berliner, C., Modarress, B., Ansari, A., \& Lockwood, D. (1988). Cost Management for Today's Advanced Manufacturing. Boston, MA: Harvard Business School Press.

Bouquin, H. (2004). Comptabilité de Gestion (3rd ed.). Economica, Paris.

Budugan, D., \& Georgescu, I. (2009). Cost reduction by using budgeting via the Kaizen method. AnaleleStiintifice ale Universitatii "AlexandruIoanCuza” din Iasi-StiinteEconomice, 56, 3-9.

CluAPU $\backslash c S N E A N U$, S., \& BRICIU, S. (2011). Analysis of the Possibility to Organize the Management Accounting through the Target Costing (TC) Method in the Romanian Entities. Theoretical and Applied Economics, 9(562). Retrieved from http://store.ectap.ro/articole/638.pdf

Ekwueme, C. M., Egbunike, F. C., \& Onyali, C. I. (2013). Benefits of Triple Bottom Line Disclosures on Corporate Performance: An Exploratory Study of Corporate Stakeholders. Journal of Management and Sustainability, 3(2), 79-81. http://dx.doi.org/10.5539/jms.v3n2p79

Ellram, L. M. (2000). Purchasing and supply chain management's participation in the target costing process. Journal of Supply Chain Management, 36, 39-51. http://dx.doi.org/10.1111/j.1745-493X.2000.tb00076.x

Epuran, M., Băbăită, V., \& Grosu, C. (1999). Contabilitatesi control de gestiune. Editura Economică, Bucuresti, 1999. 
Fischer, T. M., \& Schmitz, J. A. (1998). Control Measures for Kaizen Costing: Formulation and Practical Use of the Half-life Model. Leipzig Graduate School of Management. Retrieved from http://www.econbiz.de/archiv/ei/kuei/controlling/control_measures_kaizen_costing.pdf

Forsaith, D., Tilt, C. A., \& Xydias-Lobo, M. (2003). The future of management accounting: a South Australian perspective. School of Commerce, Flinders University. Retrieved from http://business.flinders.edu.au/research/papers/03-2.pdf

Industrial and Financial Systems (IFS). (2001). Kaizen Costing and Value Analysis, White Paper.

Innes, J., \& Mitchell, F. (1991). A Review of Activity-Based Cost Practice in Handbook of Management Accounting Practice. Butterworth-Heinemann Publishers.

Jayeola, O., Sokefun, A. O., \& Oginni, B. O. (2012). Kaizen Cost Management Technique and Profitability of Small and Medium Scale Enterprises (SMEs) in Ogun State, Nigeria. Pakistan Journal of Social Sciences, 9(3), 147-154. http://dx.doi.org/10.3923/pjssci.2012.147.154

Mishra, S., \& Gupta, A. (2010). Kaizen Culture: Enabling Organizational Change Management for Sustainable Competitive Advantage. Global Journal of Enterprise Information System, 2(2), 58-67.

Modarress, B., Ansari, A., \& Lockwood, D. L. (2005). Kaizen costing for lean manufacturing: a case study. International Journal of Production Research, 43(9), 1751-1760. http://dx.doi.org/10.1080/00207540500034174

Osisioma, B. C. (2010). Global Financial Crisis: Impact on the Changing Face of Accountancy Profession. Frontier Lecture Series 001, Department of Accountancy: NnamdiAzikiwe University.

Rof, M. L. (2012). Kaizen Costing Method and Its Role in the Management of an Entity. Revista Tinerilor Economisti (The Young Economists Journal), 104-109.

Sani, A. A., \& Allahverdizadeh, M. (2012). Target and Kaizen Costing. Retrieved from http://www.waset.ac.nz/journals/waset/v62/v62-10.pdf

Shah, H., Mali, A., \& Malik, M. S. (2011). Strategic Management Accounting: A Messiah for Management Accounting. Australian Journal of Business and Management Research, 1(4), 1-7.

Singh, J., \& Singh, H. (2009). Kaizen philosophy: a review of literature. IUP Journal of Operations Management, $8,51-73$.

Zengin, Y., \& Ada, E. (2010). Cost management through product design: target costing approach. International Journal of Production Research, 48(19), 5593-5611. http://dx.doi.org/10.1080/00207540903130876

\section{Appendix I}

Department of Accountancy

Faculty of Management Sciences,

NnamdiAzikiwe University,

Awka, Anambra State.

$1^{\text {st }}$ January, 2013

The Respondent,

\section{A RESEARCH QUESTIONNAIRE ON PRODUCT COST MANAGEMENT VIA THE KAIZEN COSTING SYSTEM: PERCEPTION OF ACCOUNTANTS.}

This questionnaire is for a study on the above named topic. The questionnaire will enable the researcher gather the necessary data relating to product cost management via the kaizen costing system. The respondent in completing this questionnaire is assured that information so contained would be treated with the utmost confidentiality, bearing in mind that the research is purely an academic exercise which is not intended for any undue disclosure of personal and/or business information.

Thanks for your anticipated co-operation.

Yours faithfully,

Egbunike, F.C. 
Instruction: Please tick ( ) for the applicable option or provide appropriate answer where necessary.

\section{SECTION A: BACKGROUND INFORMATION}

1. Name of Company

2. Sex: Male

Female

3. Nature of Industry:

Product

Service

4. Highest Level of Educational Qualification:

BSc/HND MBA/MSc PhD

(Optional) Professional Qualification (Name)

5. Length of service in the organisation:

1-10 years 11-20 years

21-30 years $\quad 31$ years and above

\section{SECTION B}

\begin{tabular}{|c|c|c|c|c|c|c|}
\hline S/No & Question Description & $S A$ & $A$ & $I D$ & $D$ & $S D$ \\
\hline 1 & $\begin{array}{l}\text { Implementing the Kaizen Costing System at the product'sintroductory phase would provide } \\
\text { management with strategies for reducing costs during the actual production process }\end{array}$ & & & & & \\
\hline 2 & $\begin{array}{l}\text { Future material procurement costs can be targeted for cost reduction alternatives during process } \\
\text { production }\end{array}$ & & & & & \\
\hline 3 & $\begin{array}{l}\text { Future labour acquisition costs can be targeted for cost reduction alternatives during process } \\
\text { production }\end{array}$ & & & & & \\
\hline 4 & $\begin{array}{l}\text { The Kaizen Costing system would enable reduction of future selling and distribution costs as } \\
\text { managers compare and select the least cost alternative }\end{array}$ & & & & & \\
\hline 5 & $\begin{array}{l}\text { Implementing an organisational based Kaizen Culture would provide the production team with } \\
\text { strategies for product improvement during design and manufacturing process }\end{array}$ & & & & & \\
\hline 6 & $\begin{array}{l}\text { Implementing the Kaizen Costing System at the product's minimal batch production phase would } \\
\text { provide management with strategies for reducing costs during the maximum batch production } \\
\text { process }\end{array}$ & & & & & \\
\hline 7 & $\begin{array}{l}\text { Implementing the Kaizen Costing System at the product's minimal batch production phase would } \\
\text { provide management with strategies for reducing raw material consumption in the maximum } \\
\text { batch production stage }\end{array}$ & & & & & \\
\hline 8 & $\begin{array}{l}\text { Implementing the Kaizen Costing System at the product's minimal batch production phase would } \\
\text { provide management with strategies for reducing labour utilization costs in the maximum batch } \\
\text { production stage as a result of the learning curve effect }\end{array}$ & & & & & \\
\hline 9 & $\begin{array}{l}\text { The Kaizen Costing System would provide the production department with strategies for product } \\
\text { development and enhancement as customer requirements are duly considered for improvements } \\
\text { purposes }\end{array}$ & & & & & \\
\hline 10 & $\begin{array}{l}\text { Implementing an organisational based Kaizen Culture would provide management with strategies } \\
\text { to improve future revenue profile as cost of production is constantly reduced }\end{array}$ & & & & & \\
\hline 11 & $\begin{array}{l}\text { Implementation of the Kaizen Costing System at the maximum batch production phase would } \\
\text { ensure that unit costs from batch production process are reduced }\end{array}$ & & & & & \\
\hline 12 & $\begin{array}{l}\text { Implementation of the Kaizen Costing System at the maximum batch production phase would } \\
\text { ensure that profitability of products in the maximum batch production phase are high as } \\
\text { products are adjusted periodically for changes in material and labour requirements }\end{array}$ & & & & & \\
\hline
\end{tabular}




\section{Appendix II}

\section{Descriptive Statistics}

\begin{tabular}{|c|c|c|c|c|c|}
\hline & $\mathrm{N}$ & Minimum & Maximum & Mean & Std. Deviation \\
\hline $\begin{array}{l}\text { Implementing the Kaizen Costing System at } \\
\text { the product's introductory phase would } \\
\text { provide management with strategies for } \\
\text { reducing costs during the actual production } \\
\text { process }\end{array}$ & 60 & 1.00 & 5.00 & 4.3667 & 1.04097 \\
\hline $\begin{array}{l}\text { Future material procurement costs can be } \\
\text { targeted for cost reduction alternatives during } \\
\text { process production }\end{array}$ & 60 & 1.00 & 5.00 & 4.5500 & .89110 \\
\hline $\begin{array}{l}\text { Future labour acquisition costs can be } \\
\text { targeted for cost reduction alternatives during } \\
\text { process production }\end{array}$ & 60 & 1.00 & 5.00 & 4.3333 & 1.05230 \\
\hline $\begin{array}{l}\text { The Kaizen Costing system would enable } \\
\text { reduction of future selling and distribution } \\
\text { costs as managers compare and select the } \\
\text { least cost alternative }\end{array}$ & 60 & 2.00 & 5.00 & 4.3000 & 1.07829 \\
\hline $\begin{array}{l}\text { Implementing an organisational based Kaizen } \\
\text { Culture would provide the production team } \\
\text { with strategies for product improvement } \\
\text { during design and manufacturing process }\end{array}$ & 60 & 1.00 & 5.00 & 4.0000 & 1.31484 \\
\hline Valid N (listwise) & 60 & & & & \\
\hline
\end{tabular}

\begin{tabular}{llllll}
\hline & $\mathrm{N}$ & Minimum & Maximum & Mean & Std. Deviation \\
\hline Implementing the Kaizen Costing System at & 60 & 1.00 & 5.00 & 4.1833 & 1.34658
\end{tabular}

the product's minimal batch production phase would provide management with strategies for reducing costs during the maximum batch production process

Implementing the Kaizen Costing System at 60

the product's minimal batch production phase would provide management with strategies for reducing raw material consumption in the maximum batch production stage

Implementing the Kaizen Costing System at 60

the product's minimal batch production phase would provide management with strategies for reducing labour utilization costs in the maximum batch production stage as a result of the learning curve effect

The Kaizen Costing System would provide $\quad 60$ the production department with strategies for product development and enhancement as customer requirements are duly considered for improvements purposes

Implementing an organisational based Kaizen 60

Culture would provide management with strategies to improve future revenue profile as cost of production is constantly reduced 


\begin{tabular}{llllll}
\hline & $\mathrm{N}$ & Minimum & Maximum & Mean & Std. Deviation \\
\hline $\begin{array}{l}\text { Implementation of the Kaizen Costing } \\
\text { System at the maximum batch production } \\
\text { phase would ensure that unit costs from batch } \\
\text { production process are reduced }\end{array}$ & 60 & 1.00 & 5.00 & 4.5667 & .88999 \\
$\begin{array}{l}\text { Implementation of the Kaizen Costing } \\
\text { System at the maximum batch production } \\
\text { phase would ensure that profitability of } \\
\text { products in the maximum batch production } \\
\text { phase are high as products are adjusted } \\
\text { periodically for changes in material and } \\
\text { labourrequirem }\end{array}$ & & & & & \\
\begin{tabular}{l} 
Valid N (listwise) \\
\hline
\end{tabular}
\end{tabular}

\section{Copyrights}

Copyright for this article is retained by the author(s), with first publication rights granted to the journal.

This is an open-access article distributed under the terms and conditions of the Creative Commons Attribution license (http://creativecommons.org/licenses/by/3.0/). 